\title{
Unrequited Love, Self-victimisation and the Target of Appropriate Resentment
}

\author{
Anca Gheaus ${ }^{1}$ (i) \\ Received: 7 July 2020 / Accepted: 10 March 2021 / Published online: 21 April 2021 \\ ( ) The Author(s), under exclusive licence to Springer Nature B.V. 2021
}

\begin{abstract}
In "Tragedy and Resentment" Ulrika Carlsson claims that there are cases when we are justified in feeling non-moral resentment against someone who harms us without wronging us, when the harm either consists in their attitude towards us or in the emotional suffering triggered by their attitudes. Since they had no duty to protect us from harm, the objectionable attitude is not disrespect but a failure to show love, admiration, or appreciation for us. I explain why unrequited love is the wrong example to use when arguing for the possibility of justified non-moral resentmentand why, therefore, Carlsson's claim remains unsubstantiated. Pace Carlsson, people who fail to return our love are not best described as harming us, but as merely failing to benefit us by saving us from harm. Moreover, their role in the causal chain that results in our coming to harm is insufficient to warrant our resentment; more plausibly, we ourselves play a greater and more direct causal role in this process. This is a welcome result: Responding with (non-moral) resentment to someone's failure to return our love indicates that our love has not taken the form of a genuine gift. When we put conditions on successful gifting by allowing for justified resentment if the gift is not returned we are not in fact giving gifts but making a bid for an exchange: I love you so that you love me back.
\end{abstract}

Keywords Love $\cdot$ Unrequited love $\cdot$ Resentment $\cdot$ Gifts

\section{Introduction}

Here is a neat, attractive and popular picture: we are justified in responding with reactive attitudes, such as resentment, to the people who wrong us, when they are morally responsible for inflicting harm on us. When we're wronged by someone, we are entitled to feel resentful about their attitude towards us because by harming us they show disrespect. They had a duty not to harm us, failed to live up to it,

Anca Gheaus

agheaus@gmail.com

1 Political Science Department, Central European University, Vienna, Austria 
and, at least in cases when they knew they had this duty, they failed to respect us as they should. The disrespectful attitude communicated by the wrongdoer warrants resentment, and therefore resentment is appropriate even when disrespect is the only wrong we suffered. At the same time, when we're harmed by agents to whom we cannot impute moral responsibility, we ought to withhold resentment, because the harming did not involve any disrespect; it wasn't up to them whether to harm us or not, or perhaps they could not understand that they were harming us. To illustrate: if you attempt to slap me in the face, I am right to resent you even if I managed to catch your arm in time to prevent you from slapping me. By contrast, if you do slap me in the face while sleepwalking there is no more reason for me to resent you than I have to resent the wind when it destroys my garden. Just like the wind, you're causally responsible for the harm I suffer, but you are not morally responsible for it.

Does this neat, attractive and popular picture exhaust the moral landscape of resentment? A Non-Moral Resentment Hypothesis, has recently been defended by Ulrika Carlsson (2018): ${ }^{1}$

There are cases when people who fail to show love, admiration or appreciation for us are harming us in virtue of these attitudes; their attitudes either constitute an objective harm to us, or cause us to suffer, or both. Since the people in question had no duty not to harm us, their attitudes towards us are not disrespectful and hence do not warrant moral resentment. Yet, because they are harming us, we are justified in feeling non-moral resentment against these people.

The Non-Moral Resentment Hypothesis is tempting because, as a matter of fact, people whose love is not requited, or who otherwise fail to secure the recognition they seek from another person, often do resent those who fail to love them (or, more generally, give them recognition.) In "Tragedy and Resentment", Carlsson claims that such resentment is warranted. Her argument is meant to apply, more broadly, to inter-personal situations involving a failure to get the love, admiration, or appreciation sought from a specific agent, but the focus is on unrequited love. Specifically, she seeks to offer "a defence of resentment as a legitimate response to tragic harm" (Carlsson 2018: 1189), where tragic harm is harm inflicted on people by agents who are not in breach of any moral duty not to harm. Such situations are similar, by Carlsson's own lights, to Bernard Williams' (1982) example of a driver who accidentally runs over a child, out of no fault of his own. In the case of the driver the harm consists in physical injury; in Carlsson's cases, it consists, in part, in the emotional injury with which some people react to the attitudes they impute to those who fail to reciprocate their love.

For the reasons I give below, Carlsson's attempt is unsuccessful; resentment towards people who blamelessly don't return our love is always unjustified. Here is the analytical structure of my argument: the emotional suffering that unrequited love often causes is, I assume, a subjective harm, and being deprived of a love life

\footnotetext{
1 This is my reconstruction of Carlsson's thesis, followed, on the next page, by my reconstruction of her argument for her thesis.
} 
may be an objective harm. Like Carlsson, I employ a non-moralised sense of harm, one that does not entail that harming is morally wrong, or even objectionable. A harm amounts to a wronging only when the harming agent is in breach of a duty not to impose the harm on their victim. I acknowledge that Scarlett comes to harm by dint of not having her love for Ashley returned but I argue, in the next section, that Ashley's lack of reciprocation is not properly described as a harming but, instead, as a failure to benefit Scarlet. Since it would be implausible to claim that all failures to benefit may justify nonmoral resentment, Carlsson owes us further explanation of why Scarlett's resentment of Ashley is justified. In the third section I explain why Scarlett's predicament should be understood either as a harming in which Scarlett herself plays the most direct causal role-that is, as a harm that Scarlett imposes on herself-or as a harm without an agent. This description of unrequited love in terms of a failure to benefit on the side of the beloved, and as (likely, and partial) self-victimisation on the side of the lover, is normatively relevant. First, my analysis matters for the proper understanding of justified resentment. It would be regrettable to think that we are justified in resenting people when, in fact, we aren't, because this would be unfair to the target of our resentment, bad for our character and likely to make us unnecessarily miserable. Second, as I elaborate in the concluding section, seeing unrequited love as a mere failure to benefit, a failure that doesn't warrant resentment, is integral to understanding love as a gift.

\section{A Mere Failure to Confer Optimal Benefit}

Carlsson argues, plausibly, that people whose love is unrequited come to harm, because most of us need and want mutual love (Carlsson 2018: 1184). Less plausibly, she also thinks that those who fail to reciprocate our love are harming us because they do not value and affirm us in the way that would fulfil our need to be loved. On one interpretation ${ }^{2}$ of Carlsson, this lack of valuing and affirmation constitutes the harm of unrequited love, if the harm is to be understood as the objective bad of being unloved by the same person we love. On another interpretation, the beloved's attitude causes the harm, understood as a host of negative emotions: when love is unrequited "we may experience great sadness and even humiliation, as our sense of self-worth is undercut" (Carlsson 2018: 1171) and can trigger the lover's anger (as it certainly does in Scarlett, see Carlsson 2018: 1180). The harm, on Carlsson's view, is explained by the fact that a failure to return love displays an attitude of the beloved which Carlsson describes as "negative"-specifically, an attitude that fails to recognise the lover in the way that they want to be recognised (Carlsson 2018: 1171, 1176). And yet, because there is no duty to reciprocate love, Carlsson also thinks that the beloved does not engage in wrongdoing, and does not disrespect the lover; the beloved is not blameworthy. She concludes that, since there is no one to blame, the harm that visits the lover is, in such cases, tragic.

\footnotetext{
${ }^{2}$ I am grateful to Jake Wojtowicz for drawing my attention to the fact that Carlsson's claim is open to two different interpretations. The two interpretations are not mutually exclusive.
} 
Yet, argues Carlsson, even if our beloved cannot help the situation - they cannot decide to reciprocate love- - this doesn't mean that they are in no way responsible for it. Following Susan Wolf (2015), Carsson argues that there exists a kind of responsibility which is neither moral nor merely causal. On this view, we can and do hold people responsible for their non-moral qualities, by responding with evaluative attitudes to some of their features over which they lack control. For instance, we can admire a friend's humour or an artist's depth of feeling without assuming that they could just as well fail to have these qualities - and, sometimes, admire them even more if we assume that such qualities are entirely beyond their control. On Wolf's view, such attitudes are "as reactive as resentment and gratitude" (Wolf 2015: 132) —in spite of the fact that the responsibility we attribute to our targets in these cases is not of the moral sort. Carlsson doesn't label this kind of non-moral responsibility, but I suggest that, for lack of a better term, we call it "identity-responsibility". 3 A failure to love back romantically is attributable to particular features of the person who does not requite love - call this person the non-lover: whom we can, and whom we cannot, love, depends on who we are. According to Carlsson, the unlucky lover is justified in resenting the non-lover in virtue of the latter's identity-responsibility. She illustrates this line of reasoning with the story of Scarlett O'Hara's unrequited love for Ashley Wilkes, from Margaret Mitchell's novel Gone with the Wind. I stick with this popular story here.

Let me clarify, from the outset, where I don't disagree with Carlsson: Like her, I believe that we all need love, including perhaps romantic love, for our flourishing (i.e. objective) and emotional (i.e. subjective) wellbeing. Further, I agree with Carlsson that a failure to have my love reciprocated can lead to great harm: this could be the case if, for a long time, I cannot shake off the pain, cannot see how anything else could make my life worthwhile, cease being able to work and love others, and end up failing in my aims and duties. I am willing to go even further than her, and suggest that, if such a need is indeed very significant and its frustration entails great emotional suffering, or an inability to function well in some central spheres of life, then inequalities in how well we are loved are concerns of justice. ${ }^{4}$ (Brownlee 2013; Gheaus 2017). Like Carlsson, I also believe that no one can owe us romantic love, and hence a failure to return romantic love cannot in itself be a breach of duty. ${ }^{5}$ Since

\footnotetext{
${ }^{3}$ Wolf's theory of this kind of responsibility may be controversial. I don't take a stand on the soundness of this view, nor on the accuracy of Carlsson's interpretation of it. My aim here is to evaluate Carlsson's own view. My major concerns in this paper are not related to identity-responsibility.

${ }^{4}$ This could mean that there is an agent of justice that is called to do something to ameliorate the situation: For instance, states may bear a duty to create the conditions in which romantic love can flourish, such as ensuring that all are educated, from a young age, about the virtues and perils of personal relationships; and that people have sufficient free time to dedicate to the cultivation of loving relationships. In addition, it may mean that states bear a duty to create social environments sufficiently inclusive to optimise the chances that everybody is able to give and receive romantic love (Brownlee 2020; Gheaus 2017). But it could also mean that we are dealing with a failure of justice understood in a purely evaluative sense, as the description of a state of affairs, rather than in a directly normative sense-that is, as generating a duty for a particular agent (Gheaus 2013).
}

${ }^{5}$ Although, arguably, there can be a breach of duty if the reason for failing to return love is an objectionable attitude towards the lover. For instance, suppose the beloved was inclined to reciprocate, but that would not allow themselves to reciprocate because the lover is black and the beloved is racist. I am open to the possibility that in this case the beloved is in breach of a duty-but it consists in their specific reason for resisting love, rather than in the mere lack of reciprocation. Alfred Archer kindly drew my attention to this possibility. 
failure to return love is not a wronging, there is no reason to react to unrequited love with indignation. Finally, I am not here taking issue with Carlsson's assumed phenomenology of love and resentment, with her identification of the harm suffered by the unlucky lover - that is, a lack of recognition and the upset this entails - and with (her reliance on) Wolf's theory of what I called "identity-responsibility". Instead, I argue that, while the lover may incur harm, the beloved is not harming her but merely failing to benefit her, and that therefore it is unfitting to react with resentment to the attitudes expressed by the failure to requite love.

In this section I argue that the most appropriate interpretation of what happens between Scarlett and Ashley is not that Ashley is harming Scarlett, but that he is failing to benefit her. If he were in control of his emotions in a way that would enable him to love her at will, his failure to do so would be aptly described not as a harming, or as a withdrawing of a benefit, but as mere allowing of harm. On the more plausible assumption that he lacks such control, the appropriate description, however, is that of a failure to benefit. Moreover, I will show that his failure-like that of many other recipients of unrequited love- - is to optimally benefit Scarlett.

The case of Scarlett and Ashley displays the following joint conditions:

a person A (Scarlett) needs $x$ (Ashley's love) if she is to avoid coming to harm;

b person B (Ashley) is the only one who can provide person A (Scarlet) with $\mathrm{x}$;

c person $\mathrm{B}$ does not owe $\mathrm{x}$ to $\mathrm{A}$.

The question is whether, in such cases, in failing to provide $\mathrm{x}$ for $\mathrm{A}, \mathrm{B}$ is doing harm to A or merely allowing harm to A. In cases when harm results from an agent's omission (here: an omission to recognise Scarlett as she wants to be recognised) rather than from actively imposing a harm, our intuitions seem to vacillate between characterising the situation as one in which the agent does or allows harm. According to one view about the distinction between doing and allowing harm, whether these cases qualify as a doing or as an allowing depends on the moral claims of the agent and the victim. That is, whether $\mathrm{B}$ harms A or merely allows harm to come to A depends on whether B owes A what A needs in order to avoid coming to harm (Woollard 2015). ${ }^{6}$ Since Scarlett has no claim to Ashley's love, his lack of reciprocation is - at least, on this view-properly described as allowing harm.

This is an intuitive verdict. Consider the following analogy: John needs to rent a room in the village where Mary lives, because he has just gotten a job there. There is a shortage of accommodation in this village, but John finds out that Mary has a

\footnotetext{
${ }^{6}$ This account is in line with the our frequent employment of a moralised concept of harm. It is intuitive to say that harm can be inflicted by the mere failure to act when it is morally required to bestow that benefit, and, at the same time, to resist the claim that harm can be inflicted by blamelessly failing to act. Imagine that a small child in a mall runs away from her father, who is distracted by a gadget. A passerby notices, but fails to run after the child and return her to her father. The child gets lost and is terribly scared: she suffers harm. On any of the currently endorsed conceptions of harm (Rabenberg 2015) it is counter-intuitive to say that the passer-by harmed the child. But it is intuitive to say that the child has been harmed by her father, who had a duty to look after her. The reason why it seems proper to say that the father has harmed the child is that he owed the child protection from that particular harm.
} 
spare room in her house and hopes he can persuade her to take him as a housemate. But, at the same time as John, another man seeking a room to rent arrives at Mary's doorstep. And Mary, who knows that the second man would make a more fitting flatmate for her, gives him the room. (This is an adequate analogy for the Scarlett and Ashley story; Ashley loves another woman, and often stories of unrequited love are stories about unhappy love triangles. But you may just as well imagine that Mary turns John down because she has good reasons to think that soon another man seeking to rent will come along, who'd make a better flatmate for her than John.) John is distressed; he just came to the harm of lacking accommodation where he needs it. Mary, let's assume, had no duty to take anyone in, let alone anyone in particular, so she's not blameworthy for not renting her spare room to John. Mary played a role in the causal history of John's lack of accommodation in the village. However, it is highly counterintuitive that she has harmed John, rather than merely allowed the harm to happen to him.

Stories of unrequited love like Scarlett's and Ashley, and many others I suspect, are relevantly similar to stories like John and Mary's. Describing them as cases not of inflicting, but of merely allowing, harm, takes away some of the initial plausibility of the claim that non-moral resentment is appropriate in these cases, because such resentment would have to target not a harming but an innocent omission. This is true in spite of the fact that Mary can be held identity-responsible for not taking John in-who makes a fitting flatmate to Mary depends on who Mary is. It would be improper for John to non-morally resent her, since she has not inflicted any harm on him but merely, and innocently, allowed him to come to harm; if so, perhaps it would be equally inappropriate for Scarlett to resent Ashley.

Perhaps some cases that involve a harm cannot be classified as either imposing or merely allowing it, but constitute a third category, that of withdrawing a benefit, and some such cases should be treated as doings while others as merely allowings (McMahan 1993). To employ a frequently discussed application, consider the difference between killing (that is, imposing a harm), letting die (merely allowing a harm) and withdrawing aid; intuitively, the last type of act aid may more readily warrant (possibly non-moral, if they involve no breach of duty) resentment than mere failure to benefit. One may be tempted to describe the case of unrequited love as one of withdrawing. But this seems a mistake. This is not at all a case of denial of resources, as in withdrawing, because in withdrawings the agent needs to perform an action to prevent the potential victim from using the resources. But Ashley doesn't do any such thing - he has never been in love with Scarlett and hence has never taken back such love. (He had fancied her; I assume taking a fancy to someone is different from loving that person.)

So far I have left open the possibility that Ashley could, indeed, bring himself to love Scarlett if she wanted-that is, that he could love her at will. But usually we think that people cannot decide whom to love romantically. This observation brings out how inappropriate it is to describe Ashley as harming Scarlett, or withdrawing love from her. But it also indicates that it may seem implausibly to describe him as allowing a harm; to allow something, one must be capable to also prevent that thing. But if Ashley cannot prevent himself from being romantically indifferent towards Scarlett, then the best description of his reaction to he is as a failure to benefit. 
Further, as in many cases of unrequited love, Ashley and Scarlett are not strangers; Ashley is her kind and benevolent friend. In some places in her article, Carlsson claims that the relevant harm of unrequited love depends on Scarlet's perception of Ashley's attitude towards her as negative. For instance, she writes that "by denying Scarlett the kind of recognition she craves from him, Ashley does have a negative attitude toward her. He does not value her the way she would like him to; he does not affirm her the way she affirms him." (Carlsson 2018: 1184) But, in fact, Ashley doesn't display any negative attitude towards Scarlett in any usual sense of the term "negative attitude". By contrast, he is her life-long friend; he admires her, wishes her well, supports her and spends some of his time with her. No matter how much would Scarlett want Ashley to have an optimally positive attitude towards her, and no matter how important her need to be loved by him, no harming through a negative attitude can be attributed to Ashley. He simply fails to display an optimally positive attitude, one that includes openness for romantic love. ${ }^{7}$ For this reason, the interpretation that I propose is that Ashley fails to optimally benefit Scarlett. Scarlett resents Ashley for failing to benefit her in the particular way in which she wants him to benefit her, by not displaying an optimally positive attitude towards her; I submit that, under this description, her resentment looks not merely unjustified, but positively objectionable, especially if he cannot choose to benefit her optimally.

Against my conclusion, one may - as Carlsson does-point to the fact that Ashley, as perhaps many people who don't requite love, feels guilt towards Scarlett. How are we to explain this feeling, which Carlsson takes as an indicator of him taking responsibility for his attitudes that putatively inflicted harm on Scarlett (Carlsson 2018: 1185)? Could such guilt-which Carlsson calls "quasi-guilt", or tragic guilt-indicate that Scarlett's resentment is justified? This is far from clear. An easy explanation of Ashley's, and other non-lovers', (rational) guilt is via a belief that he has encouraged Scarlett. After all, Ashley recognises he is a bit infatuated with her, and maybe his infatuation has shown; maybe he neglectfully encouraged Scarlett to fall in love with him. If so, then Ashley really is an appropriate target of Scarlett's resentment, but of the moralised rather than of the tragic kind: in this case, Ashley has wronged Scarlett by provoking her love while knowing he will not be able, or willing, to reciprocate. Another possibility, of course, is that Ashley's guilt is irrational, or that it is not at all guilt but, instead, regret that he cannot benefit Scarlett in the way she wants, regret which he is mistaking for guilt; neither possibility indicates the appropriateness of non-moral resentment.

\footnotetext{
7 There can be cases where the lack of reciprocation of romantic love is motivated by the appreciation, and unwillingness to jeopardise, an existing relationship — a friendship for example. Such cases show that failures to reciprocate love can express an optimally positive attitude, assuming that the beloved, in this case, sees the risk to an existing friendships as coming entirely from their inability to sustain romantic relationships. (Granted, this is not Ashley's case.) Thank you to Alfred Archer for noting this possibility.
} 


\section{Self-victimisation}

How are we to understand the cause of Scarlett's harm? Does Ashely bear any causal responsibility? Is this a case of harm without a harming? The question of who is causing Scarlett's harm seems relevant to the appropriateness of her nonmoral resentment. Indeed, Carlsson attributes to Ashley a combination of causal and identity-responsibility for the harm suffered by Scarlett. She thinks that he is harming Scarlett because the attitudes he expresses by failing to return her love make him causally responsible for the harm. This is made clear when she writes that Ashley "denies Scarlett the kind of recognition she craves from him" (Carlsson 2018: 1184). The same interpretation is suggested by the passage where Carlsson, writing about Scarlett's suffering, notes that "her broken heart is not a natural disaster, but a disaster he brought unto her." Indeed, Carlsson must attribute a combination of causal and identity-responsibility to Ashley, since an attribution of identity-responsibility alone could not possibly justify resentment. Even if one identifies, in others, features that warrant negative evaluations, and for which they can be held identity-responsible, one must, in order to make sense of one's resentment, also attribute them the relevant causal responsibility for the harm. And for such causal responsibility to be plausibly attributed, it is not enough that they play some role in the causal history that brought about one's distress. It also matters how direct, and how necessary, that role is.

The previous section's argument stayed clear of any overall assessment of the causal role that Ashley plays in Scarlett'sharm. I argued that Ashley's role is best understood as a failure to benefit Scarlett by saving her form the harm of her unrequited love for him; but if there can be causation by omission, ${ }^{8}$ does Ashley's failure to requite Scarlett's love qualify as a case of causation? Here I zoom in on that part of the harm which consists in Scarlett's emotional suffering and suggest that the causal role he plays in her emotional suffering is indirect-his romantic indifference to her is part of the causal chain that results in her suffering, but it is neither sufficient nor necessary, for her suffering. In the causal chain that connects his attitude towards her to her suffering there is another agent, who has more direct influence over Scarlett's emotional states-that is, Scarlett herself. In this section I explore the possibility that Scarlett plays a more direct causal role than Ashley in her own suffering; if so, then she, rather than Ashley, is the appropriate target of resentment.

Let me begin with a quibble: if we assume that people are not in control of whom they love romantically, some of Carlsson's description of Ashley's role is misleading: Ashley cannot deny Scarlett his love, since he lacks the ability to give it to her at will. But, be that as it may, here the interest is in the relative contribution of Ashely's and Scarlett's omissions to Scarlett's suffering and my proposal is that the suffering is causally attributable to Scarlett (to a large extent if causation by omission exists, to a lesser one if it doesn't.)

\footnotetext{
${ }^{8}$ This is a big "if", since the notion of causation by omission puzzles philosophers. See, for instance, Dowe (2010).
} 
To see this, consider the Stoic credo that we have ultimate authority in determining the emotional meaning that our circumstances have for us, and that this authority can insulate us from emotional suffering. The Stoic view consists in two claims: first, that our emotional suffering is not a direct, and hence not a necessary, response to the world, but one that is always mediated by our own interpretation of the world. Second, that we have a choice of whether or not to respond with suffering, because we have, or can acquire, control over our attitudes towards the world. ${ }^{9}$ This, second, claim may be implausibly strong: more likely, our control over what we want and how we feel is more limited. Many schools in psychotherapy, as well as the vast self-help industry are premised on these claims. The first is relevant for assessing Scarlett's self-victimisation. The second is relevant for assessing the nature of the resentment that, I argue, Scarlett is justified to direct to herself.

If the direct cause of emotional suffering is the sufferer's own desires and attitudes, then when they respond with emotional suffering to others' attitudes-in this case, a failure to display a desired form of recognition-people are at least partially causally responsible for their emotional suffering, by omitting to change their desires and attitudes. In the case of unrequited love, much of the suffering is explained by the lovers' expectations to be loved back, by their inability to let go of our hope that their love will be returned, or of the belief that only the love of a particular person can fulfil them. Some support for this claim is provided by the significant variation in people's emotional responses to having their love unreturned. There are people who, in spite of temporary sadness, seem psychologically unharmed; others lead many years of miserable and, indeed, resentful, life in the shadow of their disappointment. This variation is best understood as proof for the first Stoic claim: that other's attitudes towards us cannot be the direct cause of our emotional suffering.

Then, Ashley's romantic indifference towards Scarlett is not sufficient for her to come to harm, nor can it cause the harm directly. For such harm to visit her, she has to want his love in particular. Further, she must interpret his romantic indifference through the prism of her desires and expectations, which she fails to change. In other words, Ashley is not a proximate cause of Scarlett's suffering.

Nor is it clear that Ashley is playing a "but-for" causal role, ${ }^{10}$ and that his indifference is necessary for her coming to harm. Perhaps Scarlett, in virtue of her emotional immaturity, has a propensity for unrequited love and so would have suffered the very same subjective harms of unrequited love-the heartbreak, the humiliation, the anger-by falling in love with another man if she hadn't met Ashley. Indeed, the ending of the novel actually suggests that more harm of this kind is in store for her, in relation to another object of unrequited love. I take this as further evidence for the claim that causal role for her harm is best attributed to her, not to Ashley.

This interpretation of loving suggests that a lover can become the victim of a harm that she herself perpetrates, or whose proximate cause by omission she is. If Scarlett suffers because Ashley's attitude to her is not optimally positive-he

\footnotetext{
9 For a detailed and critical account of not only the Stoic's, but also other hellenistic philosophy schools's, take on how to acquire control over one's emotions, see Nussbaum (1994).

10 For different concepts of causation in assessing causal responsibility see Blustein (1997).
} 
recognises her as a human being, a life-long friend, and even as an attractive woman, but not as his future wife-then maybe something was amiss in her grip on reality, and this made her harbour hopes that Ashley's attitude towards her will in fact be optimally positive. In Carlsson's own words, when love is unrequited "we may experience great sadness and even humiliation, as our sense of self-worth is undercut." (Carlsson 2018: 1171, my italics). We may, but we don't necessarily experience these misfortunes. An obvious way to make sense of the modal form of the verb is that the beloved who fails to return love is not causally responsible for these harms: perhaps we ourselves are.

If we have duties of self care, to the extent to which Scarlett has some control over her desires (and isn't some such control a marker of adulthood?), she is not merely causally, but also morally responsible for the harm: She could have avoided the disaster of a broken heart, though not, perhaps, the inconvenience of disappointment. If she avoidably brought the disaster onto herself by failing to school herself out of the desire to have her love returned, then she has reason for proper reactive attitudes towards herself. This is an attractive, more mature view of loving because it attributes (some) moral responsibility for the harm of unrequited love to the lover. Indeed, this view is often implied in the ministrations that we receive from good friends when we suffer from unrequited love. The mature view of love, of course, does not entail that anybody could easily avoid all the emotional suffering of unrequited love. It only notes, since we have the power to turn ourselves into the kind of person who can let go of unfounded hopes and illusions, we bear some moral responsibility for such harm. This, of course, is compatible with thinking that, for most people, some sadness and disappointment along the way are unavoidable. It is also compatible with the thought that, as long as our emotions are not entirely in our control, we cannot take full moral responsibility for our self-victimisation, and therefore that any resentment that we may justifiably feel towards ourselves for not having prevented the harm might be, in part, non-moral.

But perhaps there is no such thing as (non-moralised) causation by omission. I am sympathetic to this view. In this case, too, there is no reason to attribute to either Ashley or Scarlett causation by omission. It is possible to still attribute some causal responsibility to Scarlett, namely to the extent to which she plays an active and direct causal role in her loving Ashley, by nourishing her hopes and expectations. But to the extent to which she doesn't fuel her desire for his love, but merely innocently fails to abandon it, her suffering is not brought about by any agent. It is a harm without harming and Ashley is, at most, a messenger. (When he tells Scarlett that he doesn't love her romantically, he informs her about a state of affairs that is harmful to her, much like Mary does when she informs John that she decided not to rent her spare room to him.). If so, then the harm of unrequited love is, indeed, on a par with the consequences of natural disasters. 


\section{Conclusion: Love as a Gift}

To take stock: sometimes people wrong us by being both causally and morally responsible for inflicting harm on us. For instance, when they intentionally slap us in the face. These are cases that combine harming with wronging. On other occasions, people harm us but they don't wrong us because they are causally but not morally responsible for the harm, or they have no duty not to harm us. In yet other cases people wrong us because, although they are not actively inflicting harm on us, they are morally responsible for the fact that we came to harm: it was their duty to prevent it. In such cases it seems apt to describe them as harming us, and moral resentment towards the wrongdoer is justified. Finally, there are cases, like the unrequited love discussed by Carlsson, when we come to a harm that someone else blamelessly fails to prevent; they fail to give us the benefit of protection from the harm.

In the particular case which is unrequited love, it seems attractive to say that part of harm-being unloved-wasn't caused by any agent. To the extent to which there is no agent who is either morally or causally responsible for the harm, there is also no target of appropriate resentment (much like in the case of the wind destroying my garden). But another part of the harm of unrequited love, emotional suffering, is caused be the victims themselves, by their failure to control their hopes, beliefs and expectations; if so, they can be held causally responsible for some of the suffering they experience. To the extent to which the harm is self-inflicted, the only appropriate target of resentment is the victim herself, and the basis of resentment is that, by failing to remove oneself from the harm's way, one failed to take proper care of oneself. And if the victim could and should have prevented some of that harm, the resentment may be moral.

If so, then Carlsson's defence of the Non-Moral Resentment Hypothesis by appeal to cases of unrequited love fails. Until and unless we have a successful defence of the hypothesis, non-moral resentment in general appears unjustified; we'd do best to try and cure any propensity for it.

Whether or not the Non-Moral Resentment Hypothesis can be vindicated, it is a good thing to see unrequited love as immune to justified tragic resentment. To conclude this essay, I point to an axiological reason for not describing the failure to return romantic love as a negative attitude that warrants (tragic) resentment. One may think that love is best understood as a gift, and that the full value of gifting is realised when the person who offers it does it without expecting anything in return. This is in tension with the assumption that when people fail to give us gifts (i.e. to love us), or to return our gifts (i.e. to love us back), they harm us by displaying a negative attitude towards us.

This observation is true even in the complicated cases in which the gift that would bring our happiness consists in the enthusiastic acceptance, and enjoyment, of the gifts we bestow on them. Indeed, this is, again, a good analogy for love: when we show our love to someone, we offer them a gift. This is a peculiar gift, one that makes the giver vulnerable in the sense that her wellbeing depends 
in part on how well this gift is received. ${ }^{11}$ When the beloved merely takes the gift politely and, as it were, puts it on a shelf out of view, never to be enjoyed, this sets back the interest of the gift-giver. The person for whom the gift is meant fails to gift us back the emotional fulfilment of knowing that they enjoyed the love we offered them. When they fail to reciprocate with their own gift of love, our interest in being loved back is further set back. Yet, if we assume that we are justified in feeling resentful when people fail to enjoy our gifts, or to reciprocate by giving us gifts in return, we deprive the very gift-giving of its full value, because we reveal that we were not into the practice of genuine gift-giving in the first place. When we put conditions on successful gifting by allowing for justified resentment if the gift receiver fails to display a particular attitude, we are not in fact giving gifts but making a bid for an exchange: I love you so that you love me back. ${ }^{12}$ To realise the genuine value of gifting, we ought to offer and accept gifts freely, without the looming threat of responding with resentment, even of the tragic kind, when there is no enjoyment or reciprocity. To give genuine gifts, one needs to accept, with grace-that is, without hard feelings - the possibility that the gifts won't be enjoyed or returned. How we think about the legitimacy of resentment as a reaction to unrequited love, then, bears on how well we realise the full value of giving and receiving love as a genuine gift.

Acknowledgements I am grateful to James Lenman, Alfred Archer, Fiona Woollard, Jake Wojtowicz and an anonymous reviewer for helpful feed-back on earlier drafts of this paper.

\section{References}

Blustein, Jeffrey. 1997. Procreation and Parental Responsibility. Journal of Social Philosophy. 28(2): 79-86.

Brownlee, Kimberley. 2013. A Human Right Against Social Deprivation. The Philosophical Quarterly. 63(251): 199-222.

Brownlee, Kimberley. 2020. Being sure of each other: an essay on social rights and freedoms. Oxford: Oxford University Press.

Carlsson, Ulrika. 2018. Tragedy and Resentment. Mind 127(508): 1169-1191.

Dowe, Phil. 2010. A Counterfactual Theory of Prevention and "Causation" by Omission. Australasian Journal of Philosophy 79(2): 216-226.

Gheaus. 2013. The Feasibility Constraint on the Concept of Justice. Philosophical Quarterly 63(252): 445-464.

Gheaus. 2017. Love and Justice: a Paradox? Canadian Journal of Philosophy 47(6): 739-775.

\footnotetext{
11 This is not to deny the stoic point. Wellbeing here is to be understood as not mere absence of suffering. And the fact that my life goes better for me in one way if my gift is well-received does not contradict the belief that my suffering at having my gift turned down would depend on my interpretation of this fact. Further, some people seem able to love others without becoming vulnerable in this way. I leave aside the question of whether such love is better than the regular, vulnerable kind.

12 On why genuine - that is, disinterested-love is not conditional on being reciprocated, see Sara Protasi (2014: 218) and Pilar Lopez-Cantero (2018: 691); both discussions concern, specifically, cases of unrequited love. Love can remain unconditional even if it is not entirely freely given in the sense outlined above; but attaching the penalty of resentment to a failure to return one's love pollutes the ideal gift-like unconditionality of love.
} 
Lopez-Cantero, Pilar. 2018. The Break-Up Check: Exploring Romantic Love through Relationship Terminations. Philosophia 46(3): 689-703.

McMahan, Jeff. 1993. Killing, Letting Die and Withdrawing Aid. Ethics 103: 250-279.

Nussbaum, Martha. 1994. The therapy of desire: theory and practice in hellenistic ethics. Princeton University Press.

Protasi, Sara. 2014. Loving People for Who They Are (Even When They Don't Love You Back). European Journal of Philosophy 24(1): 214-234.

Rabenberg, Michael. 2015. Harm. Journal of Ethics and Social Philosophy 8(3).

Williams, Bernard. 1982. 'Moral luck'. His moral luck. Cambridge: Cambridge University Press.

Wolf, Susan. 2015. Responsibility, Moral and Otherwise. Inquiry 58(2): 127-142.

Woollard, Fiona. 2015. Doing and allowing harm. Oxford: Oxford University Press.

Publisher's Note Springer Nature remains neutral with regard to jurisdictional claims in published maps and institutional affiliations. 